RADC-TR-89-39

Final Technical Report

April 1989

AD-A208 526

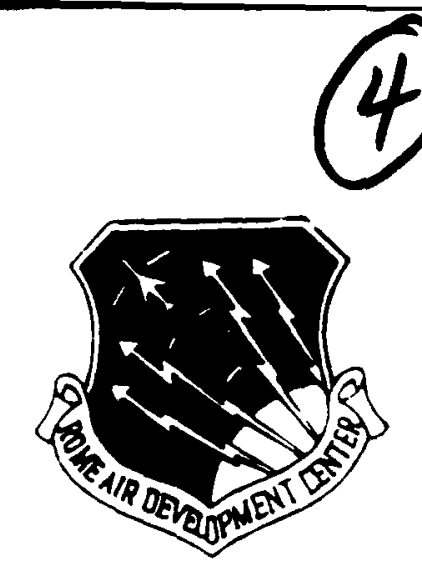

\title{
RADC SOFTWARE ACQUISITION MANAGEMENT AND ANALYSIS
}

Syracuse University

Lorraine M. Duvall

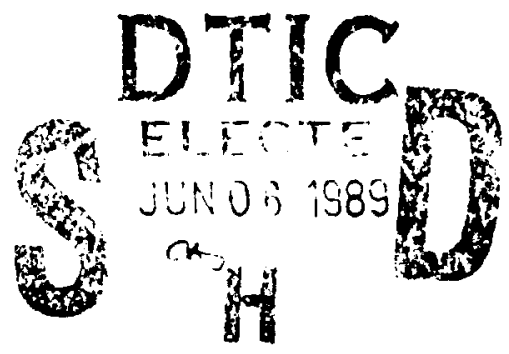

ROME AIR DEVELOPMENT CENTER Air Force Systems Command

Griffiss Air Force Base, NY 1344!-5700

$\begin{array}{llll}89 & 5 & 0 \Xi & 180\end{array}$ 
Thls report has been revlewed by the RADC PUblle Alfelro Divis and is releasable to the Natfonal Technical Informetion service (IIIs). At NTIS it will be releasable to the general, public, Including foreten meton.

RADC-TR-89-39 has been reviewed and 1s approved for pubilcation.

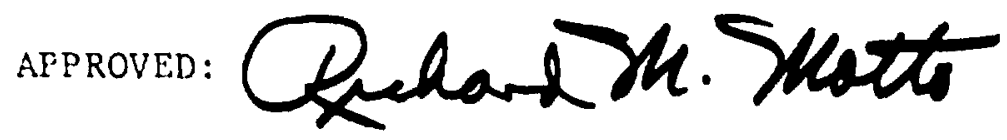

RICHARD M. MOTTO

Project Engineer

APPROVED :

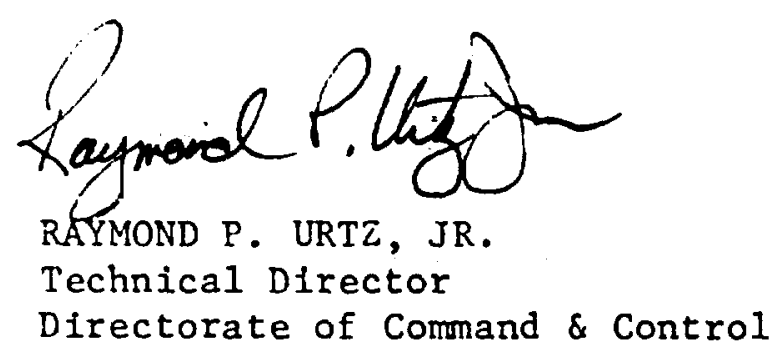

FOR THE COMMANDER:

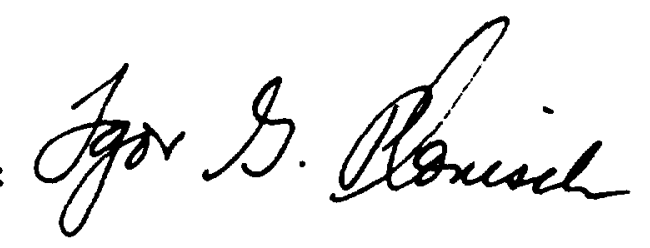

IGOR G. PLONISCH

Directorate of Plans \& Programs

If your address has changed or 1 If you wish. to be removed frox the RADC ridiling list, or if the addressee is no longer employed by volir organizaticn,

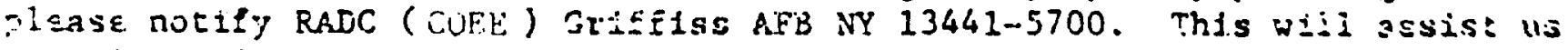
in raintaining a surrer: oalliag list.

i.o not return coples of th1s reoori: unless contractual obligatisus or noticus on a speciflc docuinent require that it be returned. 
UNCLASSIFIED

SECURITY CLASSIFICATION OF THIS PAGE

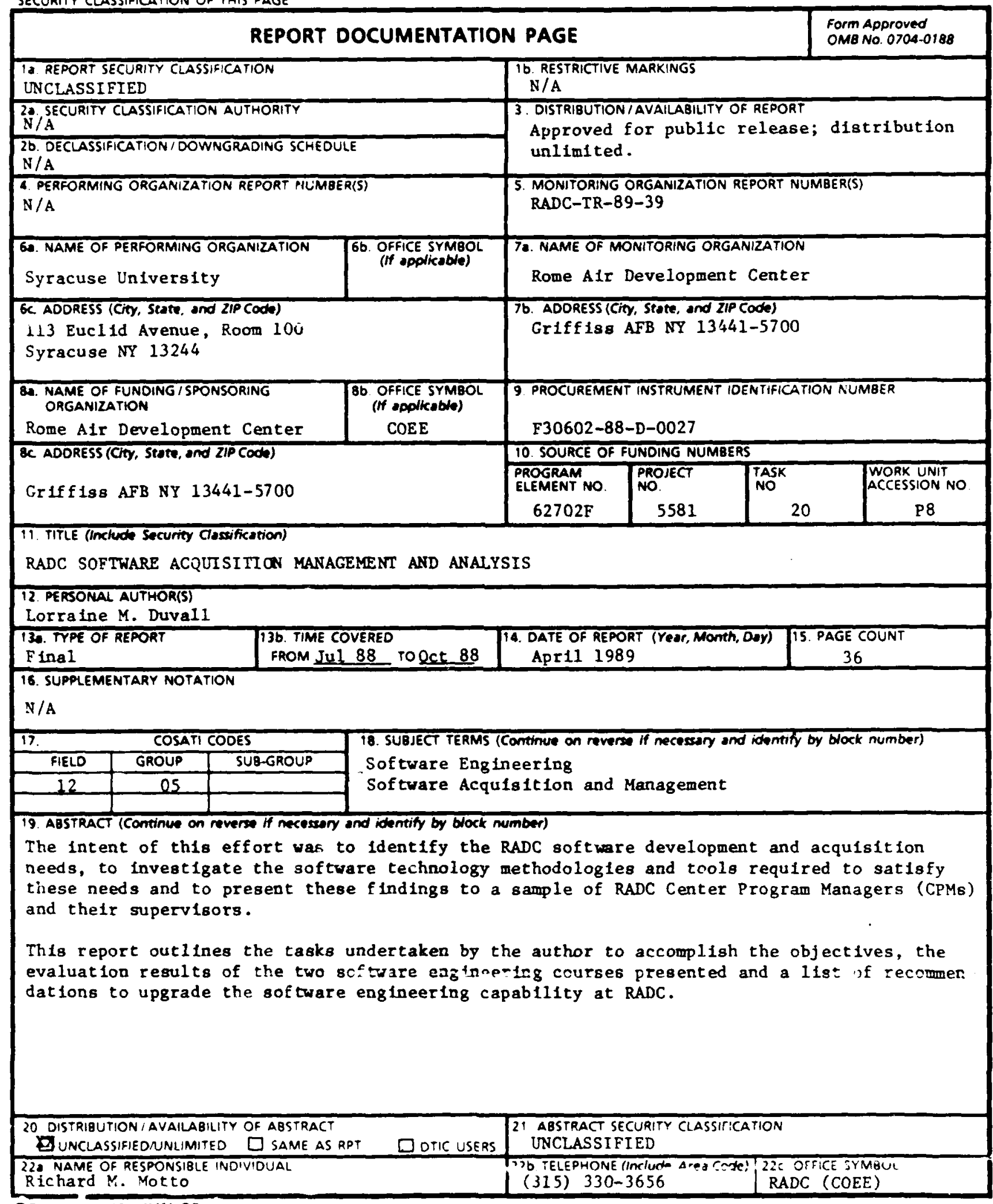

DDrorm 14/3, JUN 86 
TABLE OF CONTENTS

$\underline{\text { PAGE }}$

1.0 INTRODUCTION

1.1 objective and scope $\ldots \ldots \ldots \ldots \ldots \ldots \ldots \ldots \ldots \ldots \ldots \ldots \ldots \ldots \ldots$

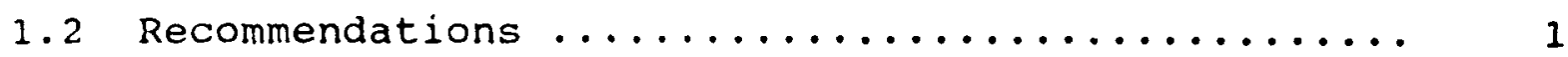

1.3 Report Contents ........................ 2

$\begin{array}{lll}2.0 & \text { INFORMATION GATHERING } & 3\end{array}$

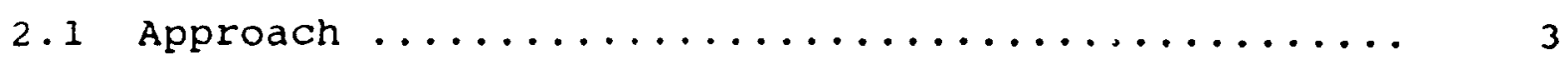

2.2 RADC Software Activities .................. 3

$2.3 \mathrm{ESD} / \mathrm{MITRE}$ Experience $\ldots \ldots \ldots \ldots \ldots \ldots \ldots \ldots \ldots \ldots$

2.3 .1 ESD Meeting $\ldots \ldots \ldots \ldots \ldots \ldots \ldots \ldots \ldots \ldots$

2.3 .2 MITRE Meeting ................... 9

3.0 SOFTWARE ACQUISITION AND MANAGEMENT COURSE 12

3.1 Course Description .................... 12

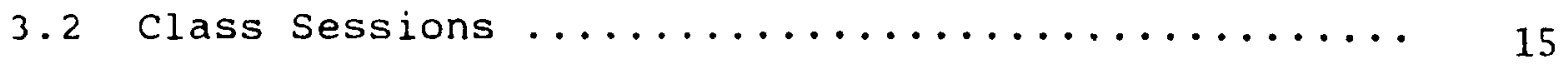

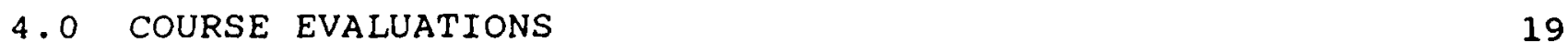

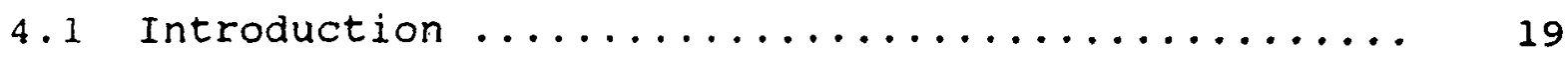

4.2 Evaluation Results .................... 19

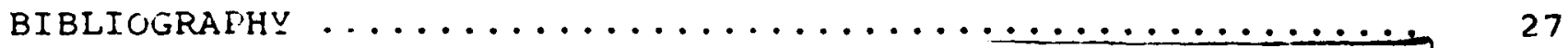




\section{LIST OF FIGURES}

\section{PAGE}

FIGURE 2-1: CATIS DOCUMENTATION ............... 7

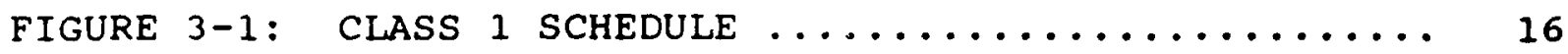

FIGURE $3-2:$ CLASS 2 SCHEDULE $\ldots \ldots \ldots \ldots \ldots \ldots \ldots \ldots \ldots \ldots$

FIGURE $4-1:$ EVALUATION FORM $\ldots \ldots \ldots \ldots \ldots \ldots \ldots \ldots \ldots \ldots$

FIGURE 4-2: EVALUATION RATING RESULTS - CLASS $1 \ldots \ldots$

FIGURE 4-3: EVALUATION RATING RESULTS - CLASS $2 \ldots \ldots 23$

LIST OF TABLES

PAGE

TABLE II-1: RADC MEETING LIST $\ldots \ldots \ldots \ldots \ldots \ldots \ldots \ldots \ldots \ldots \ldots \ldots$

TABLE IV-1: COURSE RATING - CLASS $1 \ldots \ldots \ldots \ldots \ldots \ldots \ldots$

TABLE IV-2: COURSE RATING - CLASS $2 \ldots \ldots \ldots \ldots \ldots \ldots \ldots$

TABLE IV-3: EVALUATION RESULTS -

SESSION MOST/LEAST BENEFICIAL ........ 24 


\section{INTRODUCTION}

\subsection{Objective and Scope}

The objectives of this effort were to identify RADC software development and acquisition needs, to investigate and analyze software technology methodologies and tools to help meet these needs and to recommend approaches to assist in managing the acquisition of systems where software is an integral part of the system.

Meetings were held with RADC engineers and project managers to ascertain the types of software problems encountered during the acquisition of their systems and technical and management methods employed during this acquisition process. A 4 1/2-day software acquisition and management course was designed based upon RADC requirements. This course was conducted twice during this effort to 45 RADC engineers and computer scientists and an overview of the course was briefed to 22 RADC managers and procurement personnel. An evaluation was performed to determine the effectiveness of this approach to meet the RADC acquisition needs.

\subsection{Recommendations}

The following recommendations are made based upon our understanding of RADC softivare requirements as acquired through designing and conducting the course and from an evaluation of student feedback:

- offer a 3 1/2-day course every four months. For planning purposes, provide prospective students with a course syliabus at least one month before the course is to be taught. Include in this syllabus a description of the prerequisite knowledge required of the student and provide a list of recommended readings.

- Refine the course materials to include more tutorial type information in the beginning sessions. 
- Determine the feasibility of conducting a four hour course oriented toward inexperienced students. Include introductory materials on the software engineering process using DoD-STD-2167A as the basis for a software acquisition life cycle methodology.

\subsection{Report Contents}

This report records the results of the effort expended in surveying and analyzing the RADC software acquisition needs and designing, conducting, and evaluating the software acquisition courses. The report contains four main sections including:

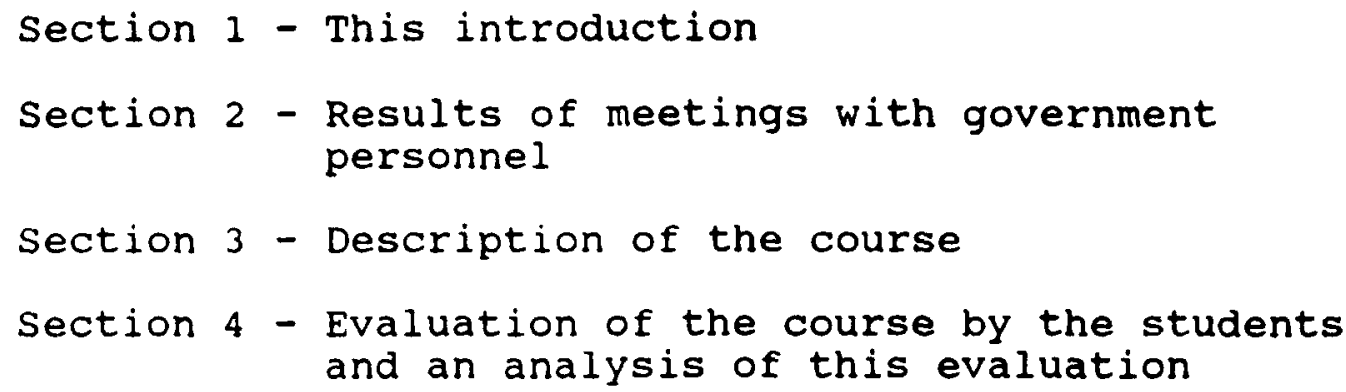




\section{INFORMATION GATHERING}

\subsection{Approach}

Meetings were held with RADC project engineers, managers, and the Directorate software Focal Points to gather information on the types of software intensive systems currently being procured at RADC, problems that are being encountered, and management and technical methods used successfully for acquiring this software. There were also meetings at the Air Force systems command (AFSC) Electronics System Division (ESD) and the Mitre corporation to discuss management and technical methodologies and tools that they have used in the procurements at ESD.

Based upon the results of these meetings, reviews of the current DoD standards and practices, the experience of the consultants from this effort, and surveys of software technology literature, an approach was developed for a suftware acquisition course to be used as a training vehicle for RADC engineers, computer scientists, and project managers. This approach was reviewed with RADC personnel. Information was gathered on RADC software procurements that could be used as examples and case studies for the software acquisition course.

Further details and results from this information gathering task are included in this section of the report.

\subsection{RADC Software Activities}

Mr. Richard Motto, RADC/COEE, was the Technical Monitor for this effort and provided insight into the software acquisition process at RADC. He is the Mission Critical Computer Resource (MCCR) Software Focal Point and represents RADC at Air Force MCCR software meetings.

Last year, Mr. Motto surveyed the five mission directorates to characterize their software acquisition activity. Since 1985, 271 software producing efforts have been awarded by RADC, broken down by Directorate, as follows: 
131 Intelligence \& Reconnaissance (IR)

76 Command \& Control (CO)

25 Communications (DC)

23 Surveillance (OC)

16 Reliability \& Compatability (RB)

Over 10 meetings were heid with Mr. Motto over the duration of the contract to acquire information on the software acquisition process and to review project status. Meetings were held with the mission directorates and contracting (PK) to acquire additional information on their software acquisition problems and lessons they have learned throughout the years. Table II-l contains a list of these meetings with an indication of purpose of the meeting and the attendees.

The acquisition needs at RADC are diverse and range from acquiring research and development, proof-of-concept software to large system procurements which contain both hardware and software elements. The type of applications vary extensively. They include, but are not Iimited to, image correlation, database systems, signal processing, smart networks, suftware tools, and battle management decision aids. Software project costs range from $\$ 100,000$ to $\$ 25 \mathrm{mili}$ ion. Estimated $\mathrm{l}$ ines of code developed range from 10,000 to 800,000 . The most frequent projects are in the 50,000 to 100,0001 ines of code range.

Implementation tools used for assisting in the software development effort include standard editors and compilers, performance coverage analyzers, and database management systems. Fortran, Ada, Pascal, COBOL, LISP, C, and assembly are the common programming languages.

Automated project management tools, test tools, and requirements design tools are used on the larger procurements. include:

Some of the major acquisition problems at RADC

- The lack of visibility of the development process

- The difficulty of applying DOD-STD-2167 and DODSTD-2167A to prototype and incremental build developments 
TABLE II-1. RADC MEETING IIST

\begin{tabular}{|c|c|c|c|}
\hline$\overline{\text { DATE }}$ & PLACE & PURPOSE & ATTENDEES * \\
\hline \multicolumn{4}{|l|}{ JULY } \\
\hline 18 & RADC/PK & $\begin{array}{l}\text { Acquisition procurement } \\
\text { issues }\end{array}$ & $\begin{array}{l}\text { A.Masercola, } \\
\text { J.Marciniak }\end{array}$ \\
\hline 19 & $\mathrm{RADC} / \mathrm{COEE}$ & Review Draft outline & $\begin{array}{l}3 \text { DCT, } 7 \text { IR, } 2 \text { CO } \\
\text { (see Iist) ** }\end{array}$ \\
\hline 19 & $\mathrm{RADC} / \mathrm{CO}$ & $\begin{array}{l}\text { Report to Directorate } \\
\text { on status }\end{array}$ & $\begin{array}{l}\text { R.Urtz, J.Marciniak, } \\
\text { A.Vito }\end{array}$ \\
\hline 22 & RADC/IRDW & CATIS fact finding & $\begin{array}{l}\text { J.Frank, P.Gwyther, } \\
\text { A.Vito, R.Motto, } \\
\text { R.Hawkins }\end{array}$ \\
\hline
\end{tabular}

AUGUST

4

RADC/IRA

3rd Floor $s / W$ problems ES development

J.Pletl, etc.

R.Motto, A.Vito

4

RADC/IRRA

1st Floor $\mathrm{S} / \mathrm{W}$ problems,

Lt.Glen Fye, ES development

R.Motto, A.Vito

4

RADC/IRDW

CATIS documentation collection

J.Frank, P.Gwyther

SEPTEMBER

15 RADC/CO OC, OP, RB, DC, PK requirements

F. Ahrens, T.Greci, K.Sherman, D. Motto, D. Lubecki

NOTES

* L. Duvall attended all the meetings

** July 19 attendees - M.Urbanik, F.Rahrig, G.Fye, J.Weher, P.Langendorf, J.Frank, R.Floyd, J.Camera, J.Pletl, J.Marciniak, A.Vito 
- The need for contractual mechanisms for changing requirements

- Contractors do not follow their own guidelines and methodologies

- The government and contractors are both learning about the DOD Standards and the tailoring rrocess

- There ars not enough resources (dollars and people) to do the proper job, and

- Engineers are inexperienced and need to be kept abreast on software technology and the use of the DOD standards

Mr. John Frank, IRDW, shared freely his projest management experience on thr acquisition of the software for the computer Aided Tactical Intelligence System (CATIS). He briefted us on the lessons learned during the development phases using DOD-STD-2167 and provided extensive dccumentation to serve as examples of Data Item Descriptions and project management methods used. Figure 2-1 contains a i.st of the documentation supplied categori-ed by major acquisition area. Lessons learned, per his briefing, include:

- Requirements must be uniquely identified

- 2167 Tailoring

- Govt responsible to tailor products required

- Contractor responsible to propose DID tailoring

- Establish clear program organization

- Develop "structured" schedules

- Require independent $Q A, C M$ and test organizations

- Pequire management \& quality metrics

- Review contractor understanding of DID's via samples

- Require structured requirements analysis

- Formalize review cycles

- Preview review packages

- Set up checklists for reviews

- Set up glossary of progran terms

- Document control/word processing system must support 2167 requirements 
SYSTEM ENGINEERINS

- Review Cuidelines

Software Specification Review (SSR)

Preliminary Desiga Review (PDR)

Critical Design Review (CDR)

- Software Development Plan (SDP)

- Minutes from Program Status Review

REQUIREMENTS

- SSR Guidelines

- Minutes from the SSR Technical Review nieeting

- Requirenents Cross Reference Document

- Requirryents Tracing Examples

- Structured Analysis Conformance Memo

DESIGN - Preliminary

- PDR Guidelines

- Sampl $ə$ Design Document

DESIGN - Detailed

- CDR Guidelines

- Sample Design Document

- Data Base Design Document

LANGUAGE ISSUES

- Software stardards and Procedures Manual

TESTING

- Software Test Plan

- Example Scenario for system Test

CONFIGURATION MANAGEMENT

- Software configuration Management Plan

QUALITY ASSURANCE

o Software Quality Evaluation Plan

EVALUATION AND ASSESSMENT

- Management Indicators

- inutes of Program Status Review \#7

SOFTWARE MANAGEMENT

- Requests for Deviation/Waivers

- Program Planning Schedules

- Pert Schedules

- Transition Plan

- Risk Analysis - Program status Review 4

- Contraci Data Requirements List

LESSONS LEARNED

o J. Frank briefing

Figure 2-1 CATIS DOCUMENTATION 


\subsection{ESD/MITRE Experience}

\subsubsection{ESD Meeting}

Lorraine Duvall and John Marciniak met with Mr. Robert Kent at the Electronics Systems Division (ESD) on July 26, 1988 to discuss ESD software acquisition methodologies. Mr. Kent presented a version of a briefing on the DOD/ESD software initiatives which included discussion revolving around the DOD software problem, ESD software organizations, and the main ESD softiare initiatives. Below is a summary of the discussion on three of these areas most relevant to RADC software acquisition issues.

\section{Contractor Capability Evaluation}

ESD sponsored the Contractor Software Engineering Asstisisent Task with the software Engineering Institute to is: $:$ ip a methodology for evaluating the capability of software englneering contraators before contract award. A second purpose : this methodology was to help contractors improve their process :or deveioping softiare. ESD tested this evaluation process at sunter (standard system center) and for Granite sentry at aACEOON. They a 50 used this for the STARS Competing primes procurement.

The actual assessments were done through the ESD/MITRE Botware center. The SEI offered some initial guidance on specific methods. They found that this audit process provided trem $\because$ th a yood indication of the contractors capabilities and should be considered as an cngoing process. They are recommending a central facility to evaluate technology on a continual basis.

be discussed the application to RADC procurements. This method could be used for some of the larger RADC efforts, with assistance provided by ESD. Information in the checklists could Le used by RADC engineers to formulate their evaluation criteria

\section{MITRE/ESD Software Reporting Metrics}

We discussed the status and use of the Mitre developed softiare management metrics. A new May 1988 report (Software Nanjement Metrics, H. P. Schultz, May 1988) includes a total of ia metras instcad of the original eight. This report also ontalins; distind recommeniations for reporting, analysis, taloring, interpretation, and data collection and has been re?ise to be compatibie with DCD-STD-2167A. 
The software metrics have been used extensively on ESD programs. They are becoming a part of the culture and are being applied tecause they are useful. Below is a list which summarizes how the metrics are being utilized:

- Historical data is used to predict future schedules and is a better forecaster than the original plans

- Unreasonableness of the plans can be illustrated graphically

- The most useful metrics are: Size, Personnel, Development Progress, and Resource Utilization

- The least useful metrics are: Complexity and volatility reports.

The data items are placed on the contractor as technical

\section{Red Team Assessments}

Red Team assessments have been conducted on approximately 20 ESD programs since 1934. These programs have been reviewed and evaluted to determine current status and to propose problem resolutions. The methods, questions asked, and lessons learned could be used on selected RADC programs, as was done on CATIS.

\subsubsection{MITRE Meeting}

Lorraine Duvall and John Marciniak met with Judy Clapp and Richard Sylvester on July 26,1988 at Mitre to discuss the major software issues at ESD. The discussions were similar to those held with Robert Kent, with some additional insight from the Mitre perspective. Below is a summary of the issues raised at the meeting.

\section{A MITRE Software Acquisition Course}

We obtained a copy of the handouts from a MITRE produced course entitled "Software Acquisition: Policy, Terminology, and Standards". This course provides an overview of the government policies, regulations, and standards which most directly affect the software aspects of ESD acquisitions. This course is in the process of being revised and will be updated to include $2167 \mathrm{a}$. 


\section{MITRE/ESD Software Reporting Metrics}

The four new metrics (design progress, design complexity, schedule progress, and requirements volatility) are beneficial because they report more items up-front.

Some lessons learned include:

- There has been improper use of the baselines, i.e the contractor changes the plans line from one month to another.

- Contractor people on the management side do not take the metrics seriously.

- There are no "tough" metrics - you have to cross reference and analyze them to clearly identify the problem areas and improvement possibilities.

- They are sometimes ignored or are recorded intermittently.

- Subcontractor data is not being collected.

o The reports are prepared and presented by the contractor at program management reviews.

Contractors are beginning to use software control Rooms that clearly show the status of programs (examples are Norden in Norialk and Grumman in Melbourne, both for the Joint STARS Program).

\section{DOD standards}

There is a concern about the amount of documentation required and the amount of time it takes the government to respond to contractor submissions. The DIDs need to be streamlined and some done away with.

We do not know how to choose the right number of CIs or the level of detail. Their experience shows that when design decisions are a part of the requirements, there may be requirements implied that need to be explicitly stated rather than buried in the details of the design.

There is concern about tailoring $2167 \mathrm{~A}$. They are waiting for guidelines. 


\section{Miscellaneous Items}

- A new Air Force Study Board has been assembled to relook at the software problem from a 1988 perspective.

- Mitre is focussing on a two step competitive process that eliminates a basic assumption that we know how to do a job before doing it.

- We obtained a copy of the February issue of the ESD/MITRE Software center newsletter which presents the lessons learned from Graybeard Source selection visits. 


\section{SOFIWARE ACQUISITION AND MANAGEMIENT COURSE}

\subsection{Course Description}

A course was designed focusing on the management of the software engineering process in the RADC environment. The orientation is from the management perspective, using DoDSTD-2167A and DOD-STD-2168 as the basis for a software management life cycle methodology.

The course provided an overall treatment of both $2167 \mathrm{~A}$ and 2168 as well as the relevant management methodologies, e.g., configuration management, quality assurance, measurement, etc., that comprise the environment. Emphasis was placed on the contracting process; what requirements should government place in the statement of work, how should the government evaluate the industry response, and what methods are best utilized throughout the development process to aid in communication between government and contractor personnel.

Techniques and guidance are provided for the statement of work, evaluation of the corresponding proposal, and the I ife cycle management processes. An in-class exercise was utilized to build confidence in the management process and provide examples of statement of work elements for each major topic area. Lessons learned from previous projects were discussed throughout the course. Examples from the IR program, CATIS, were used to illustrate the application of principles introduced. CATIS documents were also available for review during the course.

\section{TOPICS AND GENERAL OUTLINE}

1. DOD-STD-2167A. The standard is described using an evolutionary building process to develop the entire set of methodologies into a full management environment. Comparisons are made between $2167 \mathrm{~A}$ and its predecessor, 2167.

o Understand the meaning of the Software Life cycie and how it fits into the systems Life Cycle

o Overali understanding of $2167 \mathrm{~A}$ and the differences from 2167

- Understanding the relationships of the various standards used in the development of software 
- Understanding the documentation requirements of $2167 \mathrm{~A}$

- Understanding how the various methodologies, e.g., Testing, Configuration Management, Quality Assurance, etc. integrate into $2167 \mathrm{~A}$

2. Configuration Management. This session develops the formal definitions of $C M$, describes how $C M$ fits into the $2167 \mathrm{~A}$ life cycle environment, and provides treatment of $\mathrm{CM}$ in real life situations.

- Understand the role of Configuration Management in a 2167A environment

- Understand the Life Cycle issues

- Understand the role of CM tools

- Understanding of organizational issues

- Assessing CM - government prerogatives

3. Requirements and Design. These sessions provide an overview of the methodologies and tools used in defining requirements and developing designs in the context of $2167 \mathrm{~A}$.

- Develop an appreciation for the importance of requirements analysis and design to the $2167 \mathrm{~A}$ Software Life cycle

- Understand how existing methods and tools can be used in support of requirements analysis and design activities

4. Quality Assurance. This session develops an understanding of what $Q A$ is and details the use of 2168 and how it fits in a $2167 \mathrm{~A}$ environment.

- Basic understanding of $Q A$ and its employment in accordance with $2167 \mathrm{~A}$

- Understand the contractor $Q A$ organization and its relationship to the project organization

- How to build $Q A$ into the SOW and evaluate $Q A$ activities

5. Test \& Integration. This session details the process of testing in the context of $2167 \mathrm{~A}$ and describes the testing environment.

- Understand the role of Test and Integration in a $2167 \mathrm{~A}$ environment

o Understand Informal and Formal Testing 
- Understand the importance of Test Documentation

o Understand how existing methods and tools are used in support of Testing

6. Project Management. This session details a number of management issues from the perspective of how they apply to the $2167 \mathrm{~A}$ life cycle management environment, and provides cetailed guidance on the contracting process - what should the government contracting agency put into the statement of work and how should they evaluate the contractor response. Insights are provided from actual government and industry programs.

- Understand the different perspectives of the contracting Agency and the contractor

- Understanding of requirements for management processes in the Statement of Work and Proposal

- Understanding Data Rights Issues

- Understand organizational issues and how they should be treated in the statement of Work

- Understand Subcontractor Management

- Techniques for Risk Management

7. Evaluation and Assessment. This session provides insight into how the government seeks to provide visibility into project status, techniques used, etc. Guidance is provided on procedures for conducting and providing visibility throughout the life cycle process.

- Formal Reviews and Audits - Understanding detailed procedures

o Understanding the State-of-the-Art and when, if and how to apply measurements throughout the life cycle

- Understand how to apply software Management and Quality Indicators

o Understand what IV\&V is and how it relates to software development

8. Tailoring 2167A. This session deals with the various aspects of tailoring the standard from the government and industry perspectives. It covers when, why, what and how to tailor including phase in the life cycle, size of the project, and funding source. 


\subsection{Class Sessions}

Two classes were taught to a total of 45 RADC engineers and computer scientists. An additional two briefings, providing an overview of the course, were given to 22 RADC managers and procurement personnel.

The first class was attended by 27 personnel from the IR Directorate, one from the Photonics Laboratory, and one from the CO Directorate. Based upon the feedback from the attendees of this class (see section 4 of this report for a summary of the course evaluations) and the experience gained, the course was revised and given to 17 personnel from the remaining RADC Mission Directorates. Eight attended from the $C O$ Directorate, and three each from $O C$, $R B$, and $D C$.

Each class was held for $41 / 2$ days with approximately the last two hours of three of the days dedicated to working on the class exercise. The original schedule, for Class 1, is shown in Figure 3-1. The revised schedule for class 2 is contained in Figure $3-2$.

The instructors for each session are indicated in parentheses on the class schedules. Lorraine Duvall, John Marciniak, and stuart Hirshfield were instructors for both classes. Two additional instructors were used for the first class for IR to provide special insight into the problems and lessons learned from IR programs. Armand Vito, a recently retired RADC engineer, discussed the problems faced and lessons learned in recent IR procurements; John Frank from IRDW provided invaluable insight from his experience in managing the software acquisition of CATIS.

In the second class, configuration management was introduced earlier in the schedule to help alleviate some of the confusion in the first class. Also, introductory project management issues were spread throughout the course rather than dedicating an earlier session to them. All the management measures were put into one session, and the DOD standards sessions were reorganized.

Course materials were distributed to each student and consisted of approximately 500 pages of copies of the instructors' viewgraphs, DOD-STD-2167A and 2168 and the associated DIDs, and the AFSC Pamphlets for the Software Quality and Management Indicators. 
RADC Software Acquisition and Management

Class 1

MONDAY

$0800-0845$

$0845-1000$

SESSION I - Introduction

Course Introduction (LD)

Lessons Learned (JF)

SESSION II - Systems Engineering

$1000-1100$

Systems Acquisition/Software Lifecycles

(JM)

$1100-1200$

Introduction to the Class Exercise

$1200-1300$

Lunch

$1300-1430$

$1430-1630$

DOD-STD-2167A (LD)

Project Management (JM)

\section{TUESDAY}

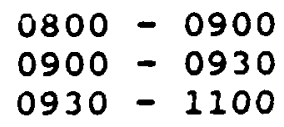

$1100-1130$

$1130-1230$

$1230-1400$

$1400-1630$

SESSION III - Requirements Analysis

Language Issues (SH)

DOD-STD-2167A Activities/Products (LD)

Requirements Methodologies, Tools and Techniques

SESSION IV - Design

DOD-STD-2167A Activities/Products (LD)

Lunch

Design Methodologies, Tools and Techniques Class Exercise

WEDNESDAY

SESSION V - Test and Integration

$0800-0930$

Test Methodologies, Tools and Techniques

(JM)

PIGURE 3-1 CLASS I SCHEDULE 16 


\section{SESSION VI - Configuration Management}

$0930-1130$

$1130-1230$

$1230-1400$
$1400-1430$
$1430-1630$

\section{THURSDAY}

Lunch

SESSION VII - Quality Assurance

QA Methodologies, Tools and Techniques Software Quality Indicators (LD) Class Exercise

\section{SESSION VIII - Project Management}

$$
\begin{aligned}
& 0800-0930 \\
& 0930-1000 \\
& 1000-1100 \\
& 1100-1200 \\
& 1200-1300 \\
& 1300-1630
\end{aligned}
$$

Software Management Techniques Management Measures (LD)

Tailoring 2167A (AV)

Software Risk Management (LD)

Lunch

Class Exercise

(JM)

\section{FRIDAY}

\section{SESSION IX - Review and Synthesis}

$$
\begin{aligned}
& 0800-1000 \\
& 1000-1100 \\
& 1100-1200
\end{aligned}
$$$$
\text { Class Exercise Review }
$$$$
\text { Lessons Learned (AV) }
$$

Course summary

$$
\text { (LD) }
$$

FIGURE $3-1$ (continued) CLASS 1 SCHEDULE 


\section{RADC Software Acquisition and Managewent}

$$
\text { Class } 2
$$

DAY/TIYE

SESSION

TOPIC

\section{MONDAY}

$\begin{array}{ll}0800-0900 & \text { I } \\ 0900-1000 & \text { II-1 } \\ 1000-1100 & \text { II-2 } \\ 1100-1200 & \text { VI } \\ 1200-1300 & \\ 1300-1400 & \text { VI } \\ 1400-1630 & \end{array}$

TUESDAY

Course Introduction (LD)

Systems Acquisition/Software Lifecycles DOD standards (LD)

Configuration Management - 1 (JM)

Lunch

Configuration Management - 2 (JM)

Introduction to Class Exercise

$\begin{array}{ll}0800-0845 & \text { III-1 } \\ & \text { IV-1 } \\ 0845-1015 & \text { II-4 } \\ 1015-1145 & \text { III-2 } \\ 1145-1300 & \\ 1300-1430 & \text { IV-2 } \\ 1430-1630 & \end{array}$

\section{WEDNESDAY}

$$
\begin{aligned}
& 0800-0930 \\
& 0930-1130 \\
& 1130-1300 \\
& 1300-1400 \\
& 1400-1630
\end{aligned}
$$

$\mathrm{V}$

VII - I

VII -2

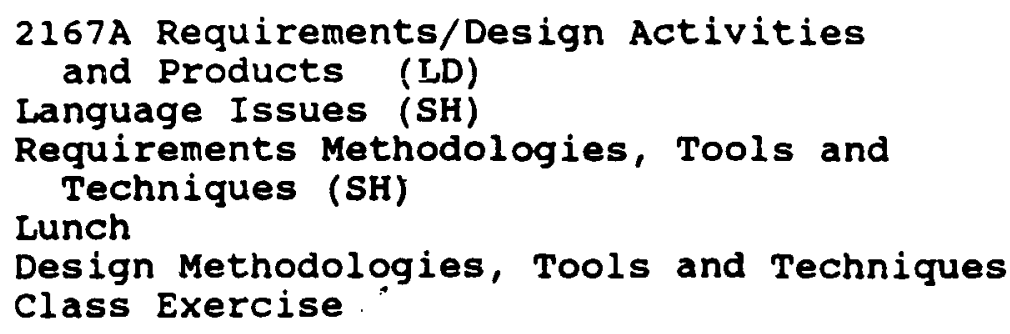

(SH)

Test Methodologies, Tools and Techniques (JM) QA Methodologies, Tools and Techniques (JM) Lunch Software Risk Management (LD) Class Exercise

\section{THURSDAY}

$0800-1000$

$1000-1100$

$1100-1200$

$1200-1300$

$1300-1430$

$1430-1630$
VIII-1 VIII-2

VIII -3

Project Management (JM)

Management Measures (LD)

Tailoring 2167A (JM)

Lunch

Class Exercise
VIII-4 Evaluation and Assessment (JM)

\section{FRIDAY}

$\begin{aligned} 0800-1000 & \text { Class Exercise Review (JM) } \\ 1000-1100 & \text { Lessons Learned (LD) }\end{aligned}$




\section{COURSE EVALUATIONS}

\subsection{Introduction}

on the last day of each course, an evaluation form was distributed to each stident (Figure 4-1). There were ten questions on this form. The first four questions asked the evaluator to rate, on a five point scale, the course in terms of job benefits, course organization, instructor effectiveness, and depth of material. Questions 5 and 6 asked which sessions were most and least beneficial. Questions 8 and 9 were directed towards obtaining feedback on the best and worst things about the course; question 7 asked for recommendations for additional material that the engineer would like to have seen covered; and question 10 was open for general comment. follows:

The number of forms returned per class are as

$$
\begin{array}{ll}
\text { Class I } & 16 \text { completed forms } \\
\text { Class II } & 11 \text { completed forms }
\end{array}
$$

This section of the report summarizes the feedback from this evaluation process and provides an analysis based upon the variations between classes.

\subsection{Evaluation Results}

Feedback from the first class was used to revise the 2nd class, which $j$ s reflected in the evaluation from the students. The second class was reorganized to provide the introduction of basic subject matter earlier in the course, depth was added to others, and some redundant materials were eliminated.

\section{OVERALL RATINGS}

Tables IV-1 and IV-2 summarize the results of the first four questions which rated aspects of the course on a five point scale from poor to very Good. These results indicate that the second class was more satisfied than the first. Fifty-six percent of the first class rated the course lood or Very Good (Questions 4 and 5 ) in terms of being beneficial to their job versus 81 percent for the second class. 


\section{RADC SOFTWARE AND ACQUISTTION AND MANAGENENT EVALNATION QUESTIONAIRE}

$\begin{array}{ccccc}1 & \text { Not } \text { so }^{2} \text { Good } & \text { Neutral } & 4 & 5 \\ \text { Poor } & \text { Good } & \text { Very Good }\end{array}$

Please circle the appropriate number.

1. How benefical will this course be to your job?

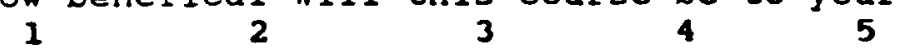

2. How was the course organization?

$12 \quad 2 \quad 3 \quad 5$

3. How would you rate instructor effectiveness?

4. How would you rate the depth of the material in meeting your needs? $\begin{array}{lllll}1 & 2 & 3 & 4 & 5\end{array}$

5. Which sessions were of most benefit to you?

6. Which sessions were of least benefit?

7. What additional material would you like to have seen covered?

8. What was the best thing about the course?

y. What was the worst thing about the course (and how would you change it)?

10. Is there anything else you would like to tell us? (Please continue on the back if you need to.) 
Table TV-1 COURSE RATING - CLASS 1

QUESTION

$$
\text { RATING - Percent Answering }
$$

$\begin{array}{lllll}1 & 2 & 3 & 4 & 5\end{array}$

1. Job benefit

12

25

50

6

2. Organization

12

44

38

6

3. Instructors

6

44

44

4. Material Depth

19

25

50

6

Average \&

(Questions $2-4$ )

12

38

44

-

0

38

4

Table IV-2 COURSE RATING - CIASS 2

QUESTION

$$
\text { RATING - Percent Answering }
$$

\begin{tabular}{lllll}
\hline 1 & 2 & 3 & 4 & 5
\end{tabular}

1. Job benefit

18

36

45

2. Organization

10

36

45

10

3. Instructors

18

64

18

4. Material Depth

18

10

55

10

Average \%

0

9

21

55

13

(Questions $2-4$ )

2: 
A better evaluation was also given for course organization, instructor effectiveness, and depth of material (Questions 2, 3, and 4) where the ratings were also significantly higher. The biggest differential occurred when evaluatiny instructor effectiveness. Eighty-two percent from the second class indicated Good or Very Good, compared to half of that, or 44 percent, in the first class.

The average percentage for Questions 2-4 are illustrated in the bar charts in Figures 4-2 and 4-3.

\section{INDIVIDUAL SESSIONS}

Questions 5 and 6 asked which sessions where of most and least benefit to the student. The results are summarized in Table IV-3 by question, class, and session.

sessions III and VIII were most liked, although not significantly. Answers to subsequent sessions provided more insight into session preference. The Exercise, Tailoring, Management Measures, and Lessons Learned were specifically mentioned as the best things about the course (Question 8). However, in class 1, it was stated that the exercise should have been more applicable to IR. A request was also made that there be more than one exercise, taking into account the different project sizes and the varying experience of the students.

\section{ADDITIONAL MATERIAL}

Question 7 asked what additional material they would like to have seen covered. Topics mentioned for class 1 were:

- Guidelines and recommendations for standards use

- Examples of principals of each block

- Real 1 ife experiences, lessons learned

- Define terms and concepts up-front

- PK relatinnships

- Specific examples related IR type programs included:

Many of the topics were similar from class 2 and

o What to do when problems arise

- The "how" of monitoring and control

- List of acronyms at end of each session

- specific tailoring quidance

- Example documents 


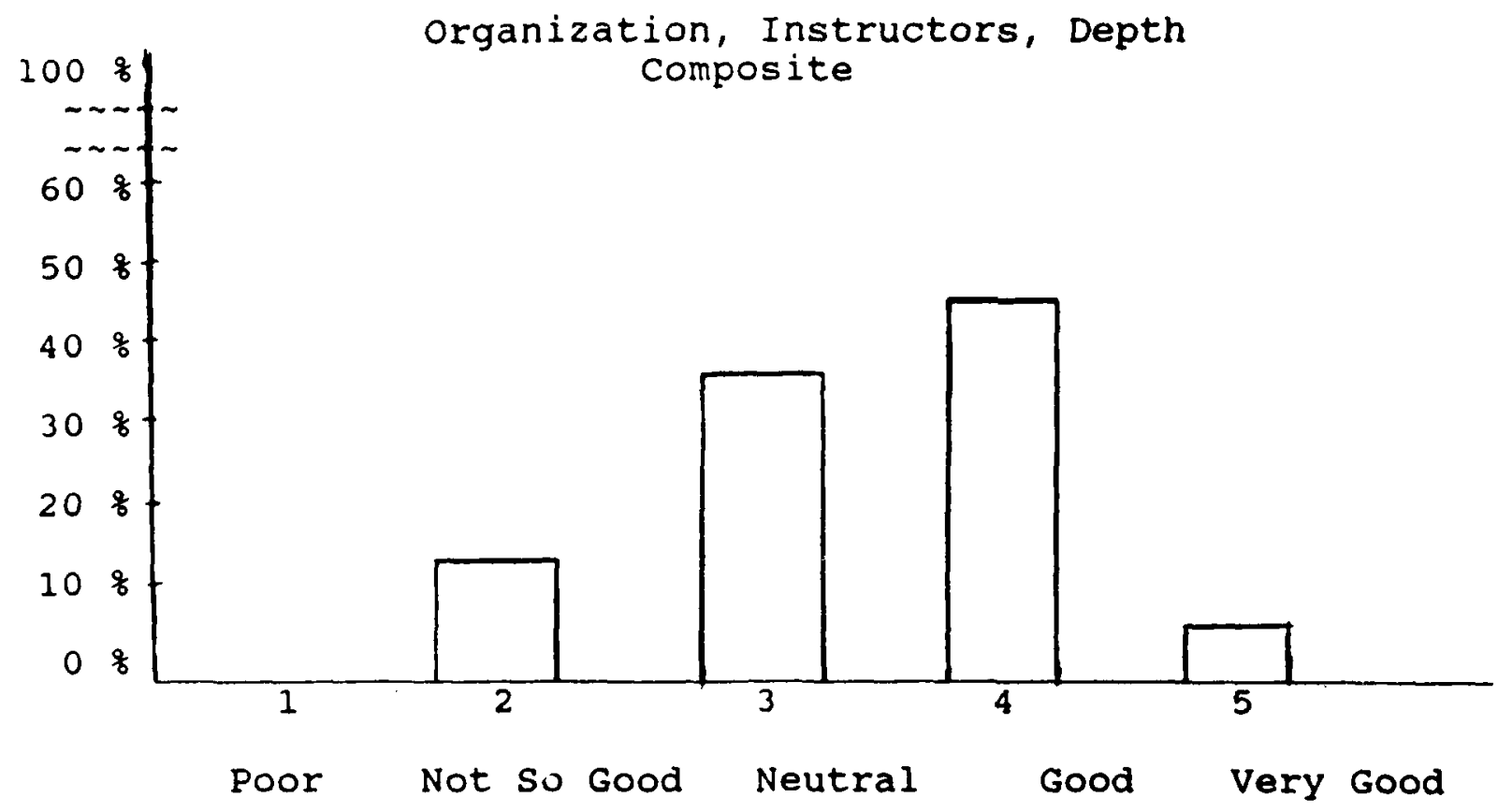

Figure 4-2 EVALNATION RATING RESULTS - CLASS 1

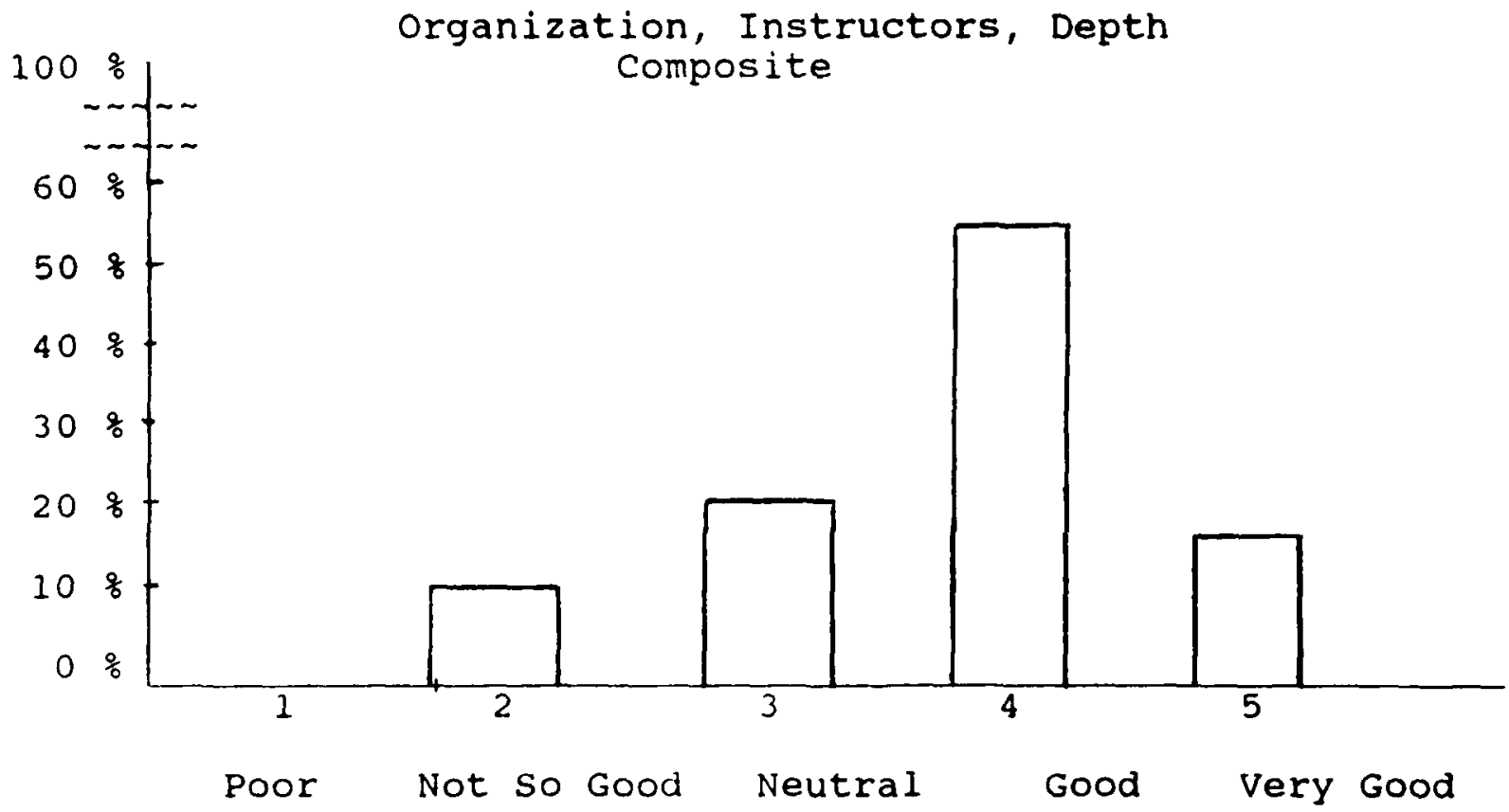

Figure 4-3 EVALUATION RATING RESULTS -CLASS 2 
Table IV-3 EVALUATION RESULTS - SESSION MOST/LEAST BENEFICIAL

\begin{tabular}{|c|c|c|c|c|c|}
\hline \multicolumn{2}{|c|}{ MOST } & \multicolumn{2}{|c|}{ LEAST } & \multirow[t]{2}{*}{ SESSION } & \multirow[t]{2}{*}{ TOPIC } \\
\hline C1 & $c 2$ & c1 & $\mathrm{c2}$ & & \\
\hline \multirow[t]{2}{*}{2} & 2 & 2 & 2 & $\mathrm{~A} 11 / \mathrm{Maj}$ & None (Least) \\
\hline & & & & I & Introduction \\
\hline 1 & $\begin{array}{l}1 \\
1\end{array}$ & $\begin{array}{l}1 \\
3 \\
1\end{array}$ & $\begin{array}{l}1 \\
1\end{array}$ & $\begin{array}{l}I I-1 \\
I I-2 \\
\text { II }-4\end{array}$ & $\begin{array}{l}\text { Systems Engineering } \\
\text { DOD Standards } \\
\text { Language Issues }\end{array}$ \\
\hline 3 & $\begin{array}{l}4 \\
4\end{array}$ & $\begin{array}{l}1 \\
1\end{array}$ & 1 & $\begin{array}{l}\text { III }-1 \\
I I I-2\end{array}$ & $\begin{array}{l}2167 \text { A Requirements Activities/Products } \\
\text { Requirements Analysis }\end{array}$ \\
\hline \multirow[t]{4}{*}{1} & $\begin{array}{l}2 \\
1\end{array}$ & $\begin{array}{l}1 \\
1\end{array}$ & 1 & $\begin{array}{l}\text { IV }-1 \\
\text { IV }-2\end{array}$ & $\begin{array}{l}2167 \text { A Design Activities/Products } \\
\text { Software Design }\end{array}$ \\
\hline & & & & $\mathrm{v}$ & Test and Integration \\
\hline & 1 & 2 & 1 & VI & Configuration Management \\
\hline & 1 & 2 & & $\begin{array}{l}\text { VII-I } \\
\text { VII-2 }\end{array}$ & $\begin{array}{l}\text { Quality Assurance } \\
\text { Software Risk Management }\end{array}$ \\
\hline $\begin{array}{l}2 \\
3 \\
4\end{array}$ & $\begin{array}{l}2 \\
2 \\
2 \\
2\end{array}$ & 1 & 2 & $\begin{array}{l}\text { VIII }-1 \\
\text { VIII }-2 \\
\text { VIII }-3 \\
\text { VIII-4 }\end{array}$ & $\begin{array}{l}\text { Project Management } \\
\text { Management Measures } \\
\text { DOD-STD-2167A Tailoring } \\
\text { Evaluation and Assessment }\end{array}$ \\
\hline 1 & & & & IX & Software Development Lessons Learned \\
\hline 4 & & 1 & 1 & & Class Exercise \\
\hline
\end{tabular}

NOTE: $\quad C 1=$ Class $1, C 2=$ Class 2 
- More time on 2167A

o Define reliability, support, tools, etc. up front

- Include sow skeletons with key insertion checklists

- Course material complete

\section{BEST AND WORST THINGS ABOUT THE COURSE}

In addition to the sessions mentioned above as being one of the best things of the course, the first class listed the following, as an answer to Question 8:

- Field experience and class discussions

- Knowledge 2167A; terminology, standards

- Totality of subject covered - difficult topic handled well

Class 2 did not list any individual sessions but made the following comments on the best things about the course:

- Exposure to the SW procurement process and open discussion with people of like interests

- Exposure to tools/techniques in use today

- Good feel for $2167 \mathrm{~A} \mathrm{~S} / \mathrm{W}$ development environment

- Dynamic lecturer

- overall structure, very clear

- What I learned, everything

- Instructors with actual background in government software management

- Very comprehensive

- Small class size, vivid discussion based on experience

Question 9 asked what was the worst thing about the course. Answers that have not previously been indicated under the session discussion include, from class 1:

- Some lectures too indepth - not general enough

o Quality of instruction, boring, too much philosophy

- Course topic of government standards

- Actual application of standards

- Mix of student experience detracted

- Bad Sow advice

- Not having been part of a $\$ 20-30$ million program 
Class 2 suggested the following on organization:

- Needs overall thread - topics jumped around

- Lack of a good introduction aimed at non-software personnel

- Too long

- No allowance for doing regular job during the week of the course

one respondee from class 2 complained that the course addressed large scale procurements and not procurements of the scale of RADC. Another wanted more material on how to apply and tailor the standard.

\section{OTHER SUGGESTIONS}

Additional suggestions from class 1, not already mentioned in relationship to other course recommendations, were directed to having two courses to handle the diversity of experience of the students where smaller efforts could be discussed specific to their needs. There was also a suggestion that there be fewer briefings, more application exercises, and more experienced instructors who have applied the theory.

Some of the additional suggestions from class 2 reflected the $\mathrm{mix}$ of hardware and software backgrounds. One respondee suggested that the course be spit into two - one for hardware and one for software personnel and that each course be a total of three days. Another said the assumptions should not be made that people have software background. Other recommendations from class 2 included:

- Compare how procurement is being done to how it should be done

- A condensed version or general overview should be presented to all engineering and computer science personnel at RADC

- suggest training be a condition of civilian promotion (like in the military) 


\section{BIBLIOGRAPHY}

Agresti, W. W., "New Paradigms for Software Development," IEEE Computer Society Tutorial, 1986.

"Air Force systems Command Software Quality Indicators, Management Quality Insight," AFSCP 800-14, 20 January 1987.

"Air Force Systems Command Software Management Indicators," AFSCP 800-43, January 1986.

"Air Force Systems Command Software Risk Management," AFSCP $800-45,1988$.

Basili, V. R., Turner, A. J., "Iterative Enhancement: A Practical Technique for Software Development," IEEE Transactions on Software Engineering, December 1975, pp. 259-265.

Bershoff, E., "Software Configuration Management," Prentice-Hall, 1980 .

Boehm, B. W., "A Spiral Model of Software Development and Enhancement," ACM Software Engineering Notes, August 1986.

Boehm, B. W., "Software Engineering Economics," Prentice-Hall, 1981 .

Charette, R. N., "Software Engineering Environments - Concepts and Technology," Intertext Publications, Inc., McGrawHill, 1986.

Conte, S. D., Dunsmore, H. E., Shen, V. Y., "Software Engineering Metrics and Models," Benjamin/Cummings, 1986.

"Configuration Management Practices for Systems, Equipment, Munitions and Computer Programs," MIL-STD-483A, June 1985.

"Contracting for Computer Software, Serious Problems Require Management Attention to Avoid Wasting Additional Millions," General Accounting office, FGMSD-80-4, November 1979.

Data Item Descriptions for DOD-STD-2167A, February 1988.

"Defense System Software Development," Military standard, DODSTD-2167A, October 1967. 
"Defense System Software Quality Program," Military standard, DOD-STD-2168, October 1987.

Evans, M. W. and Marciniak, J. J., "Software Quality Assurance \& Management, John Wiley \& Sons, 1987.

Evans, M. W. et. al, "Principles of Production Software Management," John Wiley \& Sons, 1983.

Foreman, J. and Goodenough, J., "Ada Adoption Handbook: A Program Manager's Guide," CMU/SEI-87-TR-9, ESD-TR-87-110, MaY 1987.

Grady, R. B. and Caswell, D. L., "Software Metrics: Establishing a Company-Wide Program," Prentice-Hall, Inc., 1987.

Radaty, J., "Analysis of IV \& V Data," RADC-TR-81-145, June 1981.

"Report of the Defense Science Board Task Force on Military Software," Office of the Under Secretary of Defense for Acquisition, September 1987.

Samuelson, P., et. al, "Proposal for a New "Rights in Software" Course for Software Acquisitions by the Department of Defense," CMU/SEI-86-TR-1, ESD-TR-86-203, September 1986.

Samuelson, P., "Toward the Reform of the Defense Department Software Acquisition Policy," CMU/SEI-86-TR-1, April 1986.

Schultz, H. P., "Software Management Metrics," MITRE, ESD-TR-88-001, MaY 1988.

"Software Technology for Adaptive Reliability Systems," (STARS) Business Practices Area Management Workshop, November 1985.

Software Test Handbook, Boeing Aerospace Co., NTIS No. ADA 146844, RADC-TR-84-53, 2 Volumes, March 1984.

"Specification Practices," MIL-STD-490A, June 1985.

System Engineering Management Guide, Defense systems Management College, Ft. Belvoir, VA.

"Technical Reviews and Audits for Systems, Equipments and Computer Programs," June 1985. 


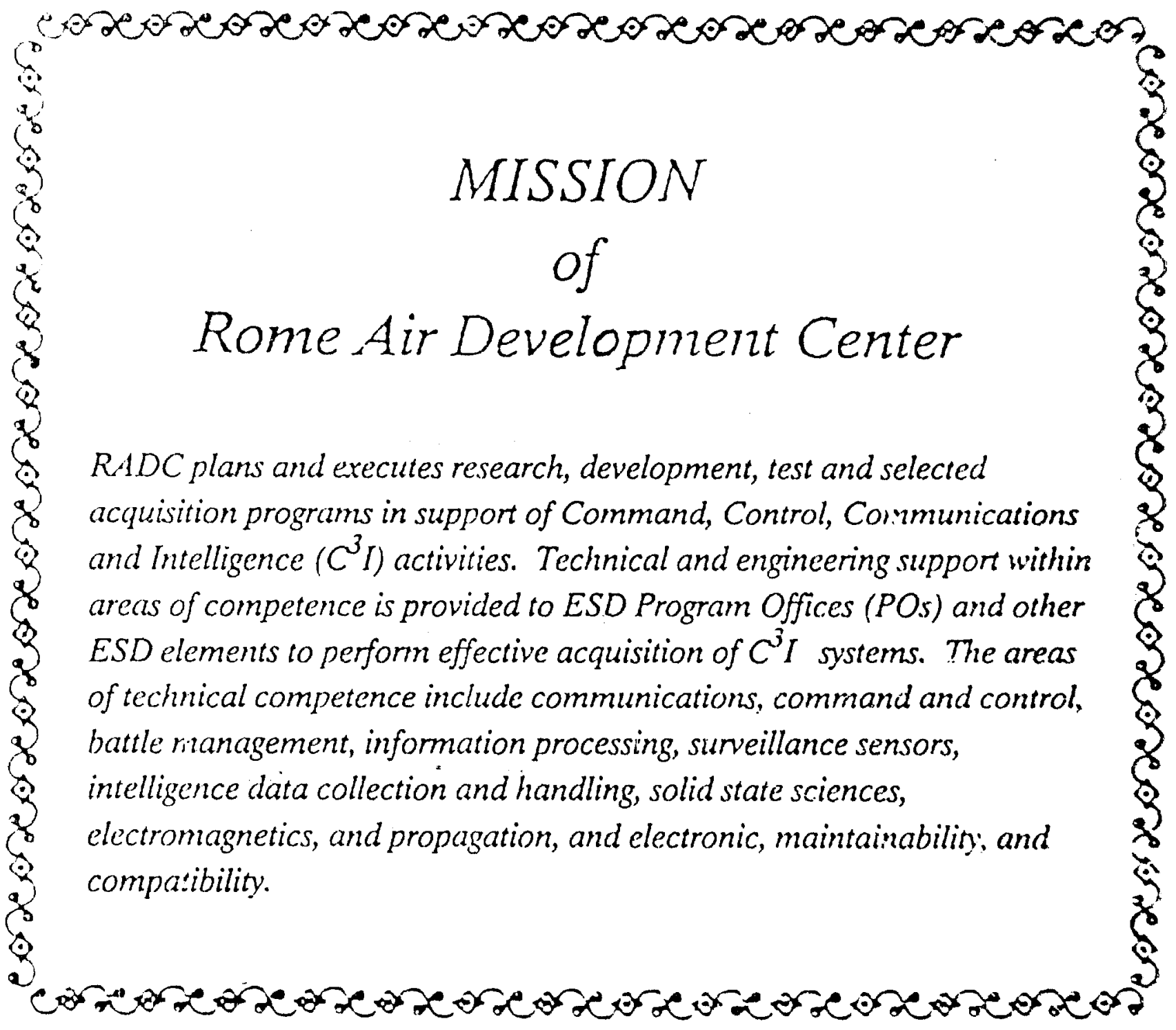

